\title{
KONSTRUKSI REALITAS COVER MAJALAH TEMPO (STUDI SEMIOTIKA GAMBAR JOKOWI BERSILUET PINOKIO)
}

\author{
Laurensia Retno Hariatiningsih ${ }^{1}$, Irwanto ${ }^{2}$ \\ Universitas Bina Sarana Informatika, laurensia.lrs@bsi.ac.id, \\ Universitas Bina Sarana Informatika, irwanto.iwo@bsi.ac.id ${ }^{2}$
}

\begin{abstract}
Abstrak
Pada September 2019 Indonesia ramai membahas revisi Undang-Undang Komisi Pemberantasan Korupsi yang disahkan, dalam kondisi ini majalah Tempo menampilkan lambang Presiden Jokowi dengan siluet Pinokio pada sampul majalah Tempo edisi 16-22 September 2019. Tujuan penelitian ini mendeskripsikan makna tanda dan simbol yang terdapat pada sampul majalah Tempo edisi 16-22 September 2019. Selain itu, ia juga ingin mengungkap makna yang terkandung dalam sampul majalah Tempo. Penelitian ini menggunakan paradigma konstruktivis, dengan pendekatan penelitian kualitatif deskriptif menggunakan model analisis semiotika triadik Charles Sander Pierce. Hasil penelitian menunjukkan bahwa tanda pria berbaju putih dengan kerutan di dahi dan bibir cemberut, hal ini menunjukkan permasalahan yang terjadi di Indonesia sehingga presiden bertanggung jawab menangani kasus korupsi. Siluet Presiden Jokowi dengan hidung panjang menyerupai Pinokio di sini merupakan penggambaran karakter Pinokio. Di sini, Tempo mencoba kritis terhadap peristiwa yang terjadi di masyarakat, dan dengan gambaran ini masyarakat memiliki persepsi sendiri-sendiri terhadap situasi saat ini.
\end{abstract}

Kata kunci: Konstruksi Realitas, Sampul Majalah, Semiotika Model TriadikCharles Sander Pierce.

\begin{abstract}
In September 2019 Indonesia was busy discussing the revision of the Corruption Eradication Commission Law which was passed, in this condition Tempo magazine depicts the symbol of President Jokowi with the silhouette of Pinocchio on the cover of the 16-22 September 2019 edition of Tempo magazine. The purpose of this study describes the meaning of the signs and symbols is included in the cover of the Tempo magazine edition dated 16-22 September 2019. Apart from that, he also wants to reveal the meaning contained in the cover of the Tempo magazine. This study uses a constructivist paradigm, with a descriptive qualitative research approach using Charles Sander Pierce's triadic semiotic analysis model. The results showed that the sign of a man dressed in white with wrinkles on the forehead and pouting lips, this shows the problems that occur in Indonesia so that the president is responsible for handling corruption cases. The silhouette of President Jokowi with a long nose resembling Pinocchio here is a depiction of Pinocchio's character. Here, Tempo tries to be critical about events in the community, and with this picture the people have their own perceptions of the current situation.
\end{abstract}

Keywords: Reality Construction, Magazine Cover, Triadic Model SemioticsCharles Sander Pierce.

\section{PENDAHULUAN}

Akhir tahun 2019 tepatnya di bulan September terjadi kondisi yang memprihatinkan di Indonesia. Revisi Undang-Undang Komisi Pemberantasan Korupsi (UU KPK) dengan mendadak disahkan oleh pemerintah, sehingga membuat masyarakat tergerak, terjadi demo dari para mahasiswa yang ada di Indonesia, selain itu ramainya pemberitaan revisi UU KPK di media membuat warganet perang komentar di media sosial. Revisi undang-undang tersebut dianggap oleh para penggiat anti korupsi dan masyarakat sebagai aturan yang dapat melemahkan KPK dan posisi KPK dinilai sedang diujung tanduk, terdapat 15 pasal yang dianggap melemahkan peran KPK memberantas korupsi, salah satunya mengenai kewenangan serta persetujuan dewan pengawas penyidik dan penyelidik dari Kepolisian Republik Indonesia dan kejaksaan. dalam melakukan penyadapan. Hal ini membuat KPK bukan lagi sebagai lembaga independent, karena penanganan korupsi harus melalui dewan pengawas. Hal ini disetujui oleh Presiden Jokowi Pada tanggal 13 
September. Selain itu ia juga menyetujui sejumlah klausal revisi UU KPK, kewenangan SP3 setelah dua tahun, hingga pegawai KPK menjadi ASN. Jokowi menyatakan menolak 4 poin revisi UU KPK, yaitu penyadapan dengan izin eksternal. Lalu penyelidik dan penyidik KPK hanya berasal dari kepolisian dan kejaksaan saja, penuntutan wajib berkoordinasi dengan Kejagung, dan LHKPN dikeluarkan dari KPK. (Detikcom, 2019). Realita mengenai sikap Presiden Jokowi ini tentu menarik perhatian media.

Media sepatutnya berdiri sebagai pengawas watch dog terhadap keadaan di ruang publik. Dalam hal ini media sebagai adalah sebuah institusi yang harus bersandar pada pilar utama kebenaran (Kovach \& Rosentiel, 2006:38). Media menyuguhkan suatu penggambaran kebenaran mengenai yang terjadi di Indonesia. Dalam memberitakan suatu peristiwa media memiliki peran dalam menggambarkan realitas yang terjadi di masyarakat.

Penelitian ini melihat bahwa simbol atau tanda pada cover majalah Tempo dengan sebuah ilustrasi gambar Jokowi Pinokio merupakan sebuah gambar yang memiliki makna tersendiri untuk dipahami secara koprehensif. Ilustrasi gambar sebagai bahasa simbolis memiliki tujuan dan arti sehingga menciptakan sebuah makna. Untuk membongkar makna yang terdapat dalam cover majalah Tempo Jokowi Pinokio, maka penelitian ini menggunakan semiotika untuk mengupas tanda-tanda, dengan melihat realitas sosial dan kebudayaan dalam tanda yang digunakan majalah Tempo pada sampulnya. Sebab da aturan yang memungkinkan tandatanda tersebut memiliki arti.

Melalui teori semiotika dapat diklasifikasikan tanda-tanda visual dan katakata yang terkandung dalam cover atau dalam hal ini sampul majalah, sebagai tujuan untuk mengungkap makna dan tanda-tanda atau simbol yang ada. (Sobur, 2009b:34)

Kajian semiotik dapat memahami kegunaan yang terdapat pada cover majalah Tempo edisi tanggal 16-22 September 2019. Dalam membongkar mengungkap makna tersirat dari cover majalah Tempo tersebut. Dalam mengungkap makna tersirat didapat dari pemaknaan yang subjektif, yang Maka semiotika yang menaruh titik pada simbol, tanda, lambang dan gambar digunakan untuk mengungkap muatan pesan yang terdapat dalam cover majalah Tempo edisi tanggal 16-22 September 2019.

Maka untuk itu penelitian ini ingin mengungkap konstruksi tanda dan memahami makna dalam cover majalah Tempo edisi edisi tanggal 16-22 September 2019, merupakan maka fokus penelitian ini adalah :

1. Bagaimana tanda-tanda dan simbol digunakan dalam pembuatan cover majalah Tempo edisi tanggal 16-22 September 2019?

2. Apa makna-makna yang terdapat dalam cover majalah Tempo edisi edisi tanggal 16-22 September 2019?

3. Konstruksi realitas apakah yang dibangun dalam cover majalah Tempo edisi edisi tanggal 16-22 September 2019?

Maksud dari penelitian ini adalah menjawab makna pria dan siluetnya yang terdapat dalam cover majalah Tempo edisi edisi tanggal 16-22 September 2019, dengan cara mengidentifikasi baik gambar, tanda-tanda dan simbol yang digunakan pada sampul atau cover. Dengan kata lain mengungkap proses pemaknaan secara subjektif terhadap cover majalah.

\section{KAJIAN LITERATUR Konstruktivisme}

Untuk menjawab pertanyaan tersebut maka perlu diphami mengenai paradigma konstruktivisme. Menurut pemahaman Berger dan Lucman konstruktivesme itu merupakan konsep relatifitas terhadap suatu realitas yang ada dan tidak ada pemikiran deduksi yang valid. Dalam disiplin ilmu komunikasi dikenal dengan teori konstruksi sosial yang berada diantara teori real sosial dan pengertian defenisi sosial (Eriyanto, 2013:13)

Pada pandangan ini subjek adalah elemen utama dalam kegiatan komunikas dan, kegiatan komunikasi serta hubungan-hubungan sosialnya. Subjek punya kuasa penuh dan punya kemampuan melakukan kontrol terhadap maksud-maksud tertentu dalam setiap wacana. Komunikasi dipahami, diatur, dan dihidupkan oleh pernyataa- pernyataan yang bertujuan. (Ardianto, 2011:156)

Paradigma konstruktivis yang memandang tindakan komunikasi sebagai suatu konstruksi sosial dari proses bedasarkan pengetahuannya dan muncul berdasarkan pengalamannya yang diinterpretasikan dalam 
bentuk makna yang dituangkan dalam suatu bentuk pesan berupa tanda, kaitannya dengan penelitian ini gambar Pinokio muncul berdasarkan pengalaman sipembuat yang dituangkan di dalam majalah Tempo, sehingga memiliki pesan tersembunyi yang ingin disampaikan.

\section{Teori Semiotika Charles Sanders Pierce}

Semiotika Charles Sanders Pierce sering kali disebut memberikan gagasannya menyeluruh, deskriptif dan struktural dari semua penandaan yang ada. Pierce melihat tanda sebagai elemen yang menjadi satu kesatuan utuh dan tunggal. (Wibowo, 2013:17). Menurutnyaa tanda sebagai medium berpikir.

Pierce mengenalkan segitiga makna. Menurutnya, semiotika berangkat dari tiga elemen utama, yang terdiri dari tanda (sign atau representamen), acuan tanda (object), pengguna tanda (interpretan).. (Krisyantono, 2006:263)

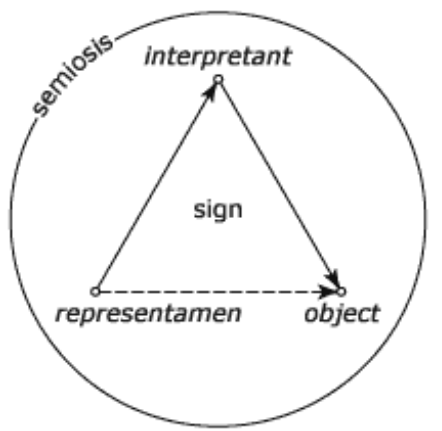

Sumber : (Wibowo, 2013:17)

\section{Gambar 1. Model Triadic Pierce}

Melalui pemikiran pierce yang tervisualisasi dengan gambar di atas maka tanda adalah konsep yang berlangsung kontinu membentuk rantai makna yang disebut dengan semiosis. Interpretan akan menjadi represent begitu terus. (Budiman, 2011:3). Sebuah alur yang tidak berwal dan berakhir.

Proses tersebut tidak ada awal dan tidak ada akhir karena semuanya saling berhubungan. Selanjutnya salah satu bentuk tanda (sign) adalah kata. Sedangkan sesuatu dapat disebut representamen (tanda) apabila memenuhi dua syarat diantaranya adalah pertama, bisa dipersepsi, baik dengan panca-indera maupun dengan pikiran atau perasan. Kedua, berfungsi sebagai tanda (mewakili sesuatu yang lain). Interpretant adalah apa yang diproduksi tanda di dalam kuasa pikiranlah yang jadi penginterpretasi;

\section{Representamen}

Representamen adalah bentuk yang diterima oleh tanda atau berfungsi sebagai tanda.Tanda atau representamen menurut Charles Sanders Peirce adalah sesuatu yang bagi seseorang mewakili sesuatu yang lain dalam beberapa hal atau kapisitas.

Sign (Representamen) merupakan bentuk fisik atau segala sesuatu yang dapat diserap pancaindra dan mengacu pada sesuatu, trikotomi pertama dibagi menjaditiga, yaitu sebagai berikut :

a. Qualisign adalah tanda yang mengacu pada sifatnya.

b. Sinsign bereferensi pada rupanya

c. Legisign sistem aturan untuk memaknai tanda

\section{Object}

Object merupakan sesuatu yang merujuk pada tanda. Sesuatu yang diwakili oleh representamen yang berkaitan dengan acuan.Pierce membedakan tanda-tanda objek dalam gambar dapat dilihat dari jenis tanda yang digolongkan dalam semiotika. Diantaranya: ikon, indeksdan simbol.

Tabel 1. Tipe-Tipe Tanda

\begin{tabular}{|c|c|c|}
\hline $\begin{array}{c}\text { Jenis Tanda } \\
\text { (Representamen) }\end{array}$ & $\begin{array}{c}\text { Hubungan Antar Tanda } \\
\text { Dan Sumber Acuan }\end{array}$ & Contoh \\
\hline Ikon & $\begin{array}{l}\text { Tanda dirancang untuk } \\
\text { mempresentasikan sumber } \\
\text { acuan melalui simulasi atau } \\
\text { persamaan (artinya, sumber } \\
\text { acuan dapat dilihat, didengar } \\
\text { dan seterusnya, dalam ikon) }\end{array}$ & $\begin{array}{l}\text { Segala macam ga } \\
\text { (bagian, diagaram dan } \\
\text { lain), photo, kata-kata } \\
\text { seterusnya }\end{array}$ \\
\hline Indeks & $\begin{array}{lrr}\text { Tanda dirancang } & \text { untu } \\
\text { mengidentifikasikan } & \text { sumber } \\
\text { acuan atau } & \text { saling } \\
\text { menghubungkansumber } \\
\text { Acuan }\end{array}$ & $\begin{array}{l}\text { Jari yang menunjuk, } \\
\text { keterangan seperti } d i \text { si } \\
\text { sana, kata ganti seperti } \\
\text { kau, ia dan seterusnya }\end{array}$ \\
\hline Simbol & $\begin{array}{l}\text { Tanda dirancang untuk } \\
\text { menyandingkan } \\
\text { acuan melalui kesepakatan } \\
\text { atau persetujuan }\end{array}$ & $\begin{array}{l}\text { Simbol sosial seperti m: } \\
\text { simbol matematika } \\
\text { seterusnya }\end{array}$ \\
\hline
\end{tabular}

Sumber: (Danesi, 2010:38)

a. Ikon adalah tanda yang mengandung unsur atau mirip. Elemen yang sangat mudah dikenali identik atau kemiripan seperti halnya tanda tanda lalu lintas.

b. Indeks bereferensi dengan eksistensial di antara representamen dan objeknya. Ada hubungan konkret antara indek dan objek.

c. Simbol,adalah tanda yang sesuai dengan kesepemahaman diantara orang yang memaknainya, seperi halnya palang merah untuk medis.

3. Intrepretan

Interpretant; adalah tanda yang terdapat dalam 
diri seseorang (Vera (2014:23) diantaranya adalah rheme, lalu dicisign, dan argument :

a. Rheme, makna tanda tersebut masih dapat diartikan.

b. Dicisign (dicentsign), ada relasi antara lambang itu dan interpretannya

c. Argument, tanda yang berlaku secara general

\section{Konstruksi Realitas Sosial}

konstruksi sosial dalam pandangan Berger dan Luckmann dimengerti sebagai satu kenyataan dan pengetahuan yang tidak hanya tersurat tapi juga tersirat. Hal ini terdapat dalam interaksi sosial pada ruang publik. Prosesnya melalui beragam lambang komunikasi ataupun bahasa dan tentunya melalui agen-agen sosial ataupun lembaga sosial yang ada. Intersubjektifitas sangat mendominasi dalam kenyataan yang ada. Pada pandangan ini juga manusia hidup memanfaatkan kognitifitas, psikomotoris, emosi dan intuitif. Melalui halhal inilah objek ditelaah secara intersubjektifitas. Namun Berger juga tidak menafikan hal objektifitas (Syam, 2005:35)

Masih dalam paendangan Berger dan Luckman, terdapat tahapan atau proses dalam pembentukan realitas sosial yakni memandang realitas sosial terbentuk sebagai proses tiga tahap, yaitu eksternalisasi, objektivasi, dan internalisasi. Ekspresi manusia terhadap dunia adalah proses eksternalisasi. Baik itu kegiatan jasmani dan rohani serta hubunganya dengan orang lain. Pada proses ini maka manusia manusia mendapati dirinya dengan cara membangun dan membentuk dunia sekelilingnya. Selanjutnya adalah objektivasi terdapat sebelum seorang individu lahir di dunia. Selanjutnya proses objektifitas dipahami sebagai pengetahuan. Inilah yang menciptakan sebuah realitas objektif bagi sebagian manusia menurut referensinya. Lalu proses internalisasi yakni saat individu ada dan menjadi bagian anggota masyarakat. Manusia sebagai produk masyarakat dihasilkan melalui proses ini. Penyerapan aturan struktur dunia yang objektif terjadi pada internalisasi. (Bungin, 2007:32)

Berger dan Luckman memandang konstruksi realitas simbolik adalah hasil cipta individu dalam kehidupan dan interaksi sosial sehari-hari. Realitas, dan kebenaran adalah hasil karya manusia yang relatif. (Noviani, 2002:13)

Lebih jauh Berger Berger dan Luckman bahwa ruang publik sangat dibutuhkan dalam melakukan konstruksi realitas. Begitu banyak motivasi yang menyertai tindakan konstruksi tersebut. Begitu juga yang terjadi dengan sampul pada majalah tempo yang menjadi fokus pada penelitian ini. Media massa jelas punya motivasi dalam melakukan konstruksi materinya. Dalam hal ini sampul majalah Tempo bergambar siluet tokoh Pinokio. Media massa telah melakukan konstruksi terhadap materi yang terdapat di dalamnya. Akan memiliki arti tertentu bila ditelaah lebih jauh.(Sobur, 2009b:32)

\section{Majalah}

Media massa cetak bisa berbentuk majalah. Majakah juga termasuk unsur komunikasi yang dikenal dengan konsep medium. Komunikasi massa yang merupakan publikasi pesan dengan menggunakan media yang ditujukan kepada masyarakat yang heterogen, yaitu sejumlah orangyang tidak dikenal dan tidak terlihat oleh penyampai pesan. (Effendy, 2006:154)

Salah satu identitas majalah adalah desain sampul atau cover yang dipunya. Lazimnya sampul majalah biasanya berisi foto, ilustrasi gambar lainnya yang biasanya memiliki unsur daya tarik. Sampul atau cover ini merupakan reprentasu dari laporan utama yang menjadi pokok isu utama dalam tiap edisinya. Hal ini biasa dikenal dengan cover stort.

Sampul atau cover ini dibuat khusus oleh desainer tertentu. Ia memperhatikan unsur kreatifitas, tata letak, korelasi dengan laporan utama, dan bahasa simbol. Karena sampul ini ada di halaman depan majalah yang langsung berinteraksi dengan mata publik saat kesan pertama. Selanjutnya desainer tersebut juga memperhatikan artistik, kontras dan ketajamannya (Rolnicki, 2008:412)

\section{METODOLOGI PENELITIAN}

Kualitatif menjadi pendekatan yang dipilih pada penelitian ini. Pendekatan tersebut untuk mendiskripsikan dan menganalisis fenomena, peristiwa, aktivitas sosial, sikap, pemikiran orang secara individual maupun kelompok. Penelitian kualitatif ini digunakan untuk melihat makna sebagai bagian yang tak terpisahkan dari pengalaman seseorang dalam konteks kehidupan sosial secara alamiah dengan mengedepankan proses interaksi komunikasi. 
Berkaitan dengan penelitian ini ingin mengetahui mengenai fenomena pemaknaan mengenai yang ada cover majalah Tempo edisi 16-22 September 2019 "Janji Tinggal Janji" secara mendalam.

Penelitian dilakukan secara interpretatif sehingga analisis perlu dilakukan untuk mendapatkan makna dari suatu fenomena guna mendapatkan pemahaman yang mendalam. Prosesnya dilakukan dengan semiotika Pierce terkait

makna gambar dari konstruksi realitas dalam gambar cover majalah Tempo edisi 16-22 September 2019.

Deskriptif dipilih sebagai Metode penelitian ini., yaitu kegiatan mengumpulkan, menganalisa, menginterpretasikan data sertamenyajikan data informasi yang sebenarbenarnya, dengan metode analisis semiotika yang menjadi titik perhatian dalam penelitian ini yaitu makna gambar pria dan siluetnya yang di konstruksi yang dituangkan dalam gambar presiden Jokowi sebagai yang digambarkan sebagai Pinokio di majalah Tempo. Peneliti akan memperhatikan koherensi makna antara bagian-bagian dalam teks yang terdapat dalam cover majalah Tempo Jokowi pinokio dan melakukan interpretasi untuk mengungkap makna yang tersembunyi dalam cover majalah tersebut.

Unit analisis dalam penelitian ini adalah semua tanda-tanda yang dalam kaitannya penelitian ini adalah baik visual, tulisanwarna, pemilihan tokoh, background dan gurtan yang terdapat dalam cover majalah Tempo edisi 1622 September 2019, yang kemudian elemenelemen ini akan diinterpretasikan dengan menggunakan model Triadic Charles Sander Pierce.Elemen-elemen pada cover majalah ini akan dianalisis dengan memulai fokus kepada representamen, objek dan interpretan. Dengan mengklasifikasikan tanda atau representamen, menjadi qualisign, sinsign, dan legisign. Selanjutnya mengaitkan tanda dengan objek dengan membagi tanda atas ikon, indek dan simbol. Selanjutnya adalah interpretan, tanda (sign, representamen) dibagi atas rheme, dicent sign atau dicisign dan argument.

\section{Metode Pengumpulan dan Sumber Data}

Dialog tanya jawab dilakukan dengan mewawancarai pembuat cover majalah Tempo edisi 16-22 September 2019 yaitu Kendra
Paramita, guna mendapatkan data yang lebih dalam dan memperkuat penelitian sehingga menjawab masalah penelitian. Secara konteks tual yang paling bertanggung jawab terhadap sampl majalah tempo adalah Kendra Paramita. Ia sebagai pembuat cover majalah Tempobedisi 19-22 September 2019, beliau dianggap tepat karena sebagai yang membuat cover majalah tersebut dan yang mengetahui maksud dari gambar tersebut.Teknik observasi yang dilakukan yaitu dengan observasi keterlibatan langsung pasif yang diobservasi hanya pada bagian-bagian yang terdapat dalam cover majalah Tempoedisi 16-22 September 2019, yakni berupa gambar, teks atau tulisan, warna, pemilihan tokoh, pemilihan latar Data lain yang mendukung juga digunakan sebagai materi dalam menagnalisa. Seperti halnya dari sumber tertulis dan literatur, seperti arsip, dokumen resmi, tulisan-tulisan yang ada pada situs internet, yang dapat mendukung analisa penelitian tentang simbol-simbol dan pesan yang terdapat pada cover majalah Tempo edisi 16-22 September 2019.

Sebagai upaya untuk memvalidasi data maka ini menggunakan metode triangulasi sumber, yaitu menggunakan sumber data berdasarkan hasil wawancara sebagai penguat karena dianggap sebagai subjek yang memiliki sudut pandang yang berbeda. Selain itu menggunakan triangulasi metode, yaitu dengan cara mencari data lain tentang sebuah fenomena yang diperoleh dengan menggunakan metode yang berbeda yaitu wawancara, observasi, dan dokumentasi, hal ini digunakan untuk menggambarkan data, menghubungkan dan menyimpulkan data yang dapat dipercaya.

\section{Teknik Analisis Data}

Tahap dalam analisa data yang umum dilakukan dalam penelitian kualitatif, Huberman dan Miles, yaitu :

1. Kategorisasi dan Reduksi Data

2. Penyajian Data

3. Penarikan Kesimpulan atau Verifikasi

Penelitian ini akan mengkaji cover majalah Tempo edisi 16-22 September 2019 dengan menganalisis tanda menggunakan semiotika model Charles Sanders Peirce sebagai teori segitiga makna (triangle meaning) yang membagi tanda atas representamen, object dan interpretant. 


\section{PEMBAHASAN}

Dalam bab ini akan membahas mengenai temuan dari permasalahan pokok penelitian dengan menganalisis objek penelitian dengan menggunakan teori triadict Charles Sanders Peirce dengan menguraikan representamen (sign), object, dan interpretant. Dalam penelitian ini objek penelitiannya adalah cover majalah tempo edisi 19-22 September 2019, dengan gambar sebagai berikut:

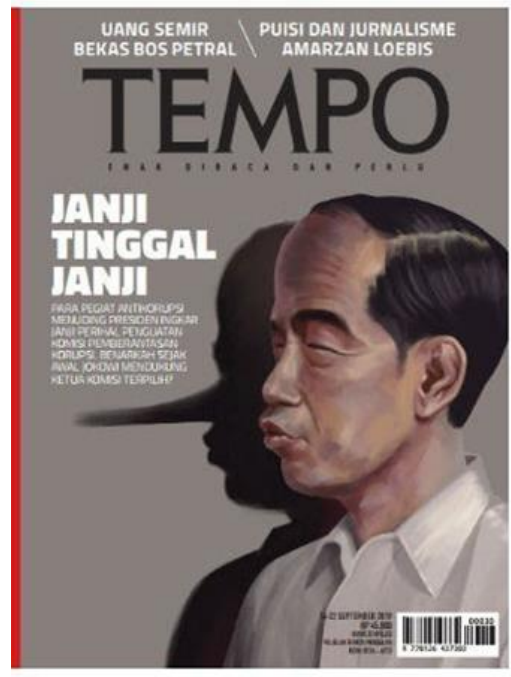

Sumber : (Riana, 2019)

Gambar 2. Cover Majalah Tempo Edisi 1622 September 2019

1. Representamen Cover Majalah Tempo Edisi 16-22 September 2020.

\begin{tabular}{|c|c|c|}
\hline \multicolumn{3}{|c|}{ Representamen } \\
\hline Qualisign & Sinsign & Legisign \\
\hline $\begin{array}{l}\text { Kecemasan, kecewa, tidak } \\
\text { mau tau, keresahan, } \\
\text { kebohongan ini masuk } \\
\text { sebagai reprentamen dalam } \\
\text { katagori qualisign. }\end{array}$ & $\begin{array}{l}\text { Gambar presiden Jokowi } \\
\text { dengan siluet menyerupai } \\
\text { gambar Jokowi dengan } \\
\text { siluet hidungnya lebih } \\
\text { panjang dan terdapat teks } \\
\text { Janji Tinggal Janji. }\end{array}$ & $\begin{array}{l}\text { Janji yang tidak ditepati, } \\
\text { kebohongan, } \\
\text { keberpihakan. }\end{array}$ \\
\hline
\end{tabular}

Representamen atau tanda dalam cover majalah Tempo ini terlihat latar belakang berwarna abu-abu, disertai ilustrasi seorang pria mengenakan baju putih dengan bibir dimajukan kedepan, mata meram dengan rambut belah kesamping dan terdapat kerutan dikeningnya. Teks yang tertulis dalam cober majalah Tempo tersebut yaitu "Janji Tinggal Janji: Para Penggiat Anti Korupsi Menuding Presiden Ingkar Janji Prihal Penguatan Komisi Pemberantasan Korupsi, Membenarkan Sejak Awal Jokowi Mendukung Ketua Komisi Terpilih".
2. Objek Sampul Majalah Tempo Edisi 16-22 September 2020.

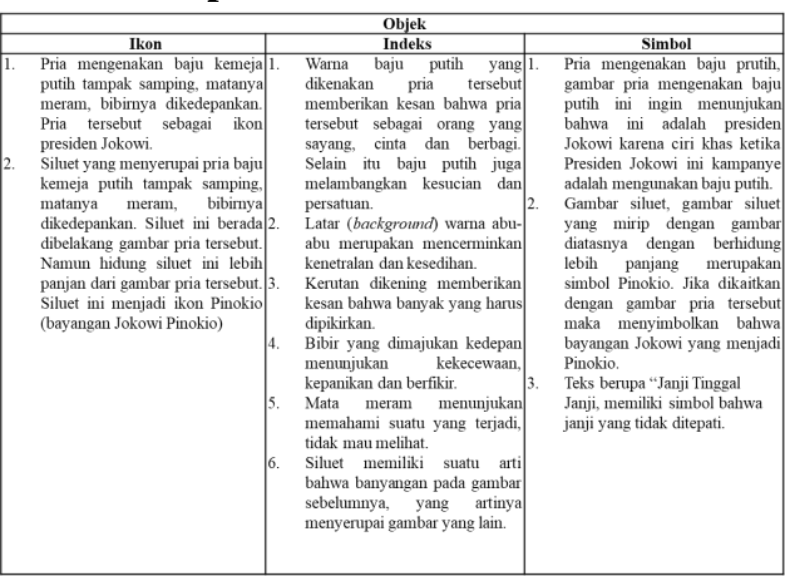

3. Interpretan Sampul Majalah Tempo Edisi 16-22 September 2020.

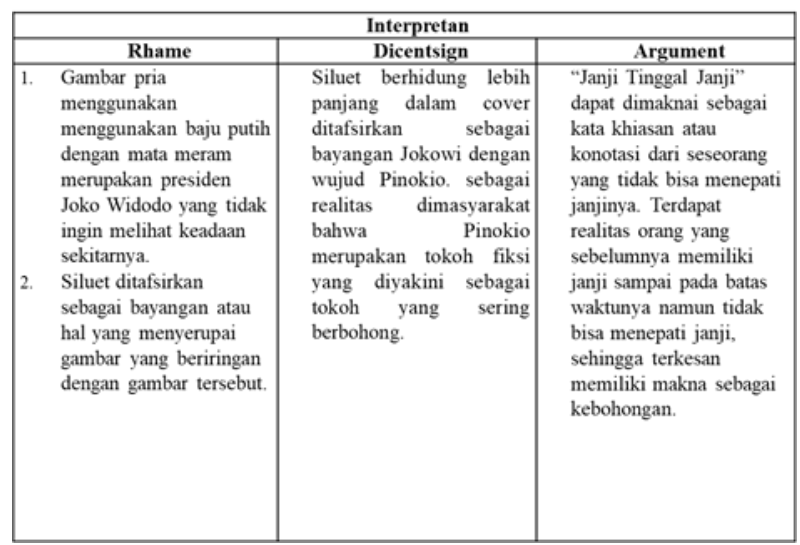

\section{Realitas dalam Sampul Majalah Tempo Edisi 16-22 September 2019}

Berger dan Luckmann untuk memahami konstruksi sosial dimulai dengan mendifinisikan apa yang dimaksud dengan kenyataan dan pengetahuan. Kenyataan sosial dimaknai sebagai sesuatu yang tersirat didalam pergaulan sosial yang diungkapkan secara sosial melalui komunikasi lewat bahasa, bekerjasama melalui bentuk-bentuk organisasi sosial. (Syam, 2005:35)

Realitas dapat dimaknai melalui teks bahasa seperti dalam penelitian ini pada cover majalah Tempo yang terdiri dari suatu simbol baik itu gambar maupun kata-kata. Bahasa merupakan medium yang menjadi pelantara dalam memaknai sesuatu, memproduksi dan mengubah makna. Melalui bahasa dapat mengkomunikasikan sesuatu pesan yang ingin disampaikan, dan lewat bahasa tertuang simbol atau tanda dalam mengungkapkan pikiran, konsep, dan ide 
mengenai sesuatu.

Dengan menggunakan model triadic dan konsep trikotominya Charles Sanders Peirce dengan menghubungkan representamen (sign) dengan objek yang kemudian akan terbentuk interpretan (pemaknaan) dalam pemikiran peneliti bahwa cover majalah tersebut bahwa mengacu kepada suatu realitas yang terjadi, cover majalah ini juga akan dihubungkan dengan teori dan sumber lain yang menyangkut realitas berdasarkan refrensi yang digunakan peneliti.

Cover majalah Tempo merupakan gambar tersebut merupakan metafora dari pemberitaan dalam majalah tersebut, yakni keresahan terhadap revisi UU KPK serta tanggung jawab dari pemerintah. (Setiawan, 2020) Siluet yang menyerupai gambar presiden Jokowi, siluet ini berada dibelakang gambar pria tersebut. Namun hidung siluet ini lebih panjan dari gambar pria tersebut, Siluet ini ditafsirkan sebagai Pinokio, jika siluet diartikan sebagai bayangan, maka dari itu siluet gambar jokowi diartikan sebagai bayangan Jokowi yang menyerupai Pinokio. jika dikaitkan dengan headline dan subheadline "Janji Tinggal Janji: Para Penggiat Anti Korupsi Menuding Presiden Ingkar Janji Prihal Penguatan Komisi Pemberantasan Korupsi, Membenarkan Sejak Awal Jokowi Mendukung Ketua Komisi Terpilih". Dari sini terlihat bahwa ada yang ingin disampaikan, terlihat penggambaran presiden Jokowi dianggap berbohong terkait dengan janjinya untuk mendukung KPK, namun kenyataannya revisi UU KPK tetap akan disahkan. Seperti yang dijelaskan oleh pembuat ilustrator dalam wawancaranya sebagai berikut:

"Sampul ini berbicara tentang janji atau tentang broken promise atau hal-hal yang tidak ditepati, pernyataan tidak sesuai dengan kenyataan". (Paramita, Wawancara 2020)

Penggambaran yang terdapat di dalam cover majalah Tempo sebagai gambaran mengenai kritis Tempo terhadap kondisi yang terjadi saat ini. Kritis Tempo memiliki pandangan yang sesuai dengan ekspetasi khalayak.

"Sampul ini tidak terjadi begitu saja, beberapa orang bilang kita bikin sampul cukup keras terhadap pemerintah, nyentil banget gitu kan tapi ini tidak terjadi begitu saja kalau kita lihat cover-cover sebelumnya baik dari Koran Tempo maupun majalah Tempo itu kita mulainya soft banget... Jadi memang tidak terjadi begitu saja, tapi berangsur-angsur menjadi besar karena aaaa dari merekanya juga tidak ada perubahan gitu kan, perubahan kearah yang lebih baik, jadi kami merasa perlu memberikan sesuatu yang lebih keras gitu". (Paramita, Wawancara 2020)

Cover majalah Tempo disini tidak dibuat tanpa alasan, maupun memiliki tujuan, karena melihat fenomena yang terjadi yang ada dimasyarakat maupun pemerintahan. Untuk kasus yang menyangkut kasus yang besar yang menuntut harus adanya perubahan dari pemerintahan majalah Tempo cukup keras menyentil pemerintah, disini Tempo berusaha untuk mengkritisi pemerintah. Hal ini sesuai dengan ideologi majalah Tempo itu sendiri sebagai ideologi majalah Tempo yang bersifat kritis sesuai dengan konstitusi serta ruh demokrasi pada suatu media. (Setiawan, 2020:82) Dan visi dari majalah Tempo itu sendiri sebagai media yang menjadi acuan dalam proses kebebasan rakyat untuk berfikir dan mengutarakan pendapat, serta membangun suatu masyarakat yang menghargai kecerdasan dan perbedaan pendapat.

Hal ini juga dipertegas oleh Kendra Paramita (Pembuat Cover Majalah) sebagai berikut :

"Dari ilustrasi yang dibuat Tempo ingin masyarakat memiliki kritis terhadap keadaan saat ini, tidak ada pesan khusus yang ingin disampaikan, namun Tempo ingin masyarakat memiliki persepsi sendiri terhadap situasi saat ini. Terjadi Multitafsir dan multiinterpretasi itu jadi bisa bermacammacam artinya. Baik yang positif ataupun negative ataupun netral. Jadi sebenernya kita tidak bermaksud untuk menetapkan sebuah statement yang spesifik begini begini begini itu engga, tapi kita lebih senang membebaskan tafsir kepada para pembaca, Jadi pembaca terlibat gitu, jadi mereka juga bebas untuk menafsirkan sendiri gambar ini gitu. Jadi pembaca terlibat gitu, jadi mereka juga bebas untuk menafsirkan sendiri gambar ini gitu, kami lebih memilih seperti itu. lebih senang dengan cara seperti itu gitu. Jadi hmm 
yang kami sampaikan disini hanya sebatas, oke ini hmm sampul ini berbicara tentang janji atau tentang broken promise atau hal-hal yang tidak ditepati, pernyataan tidak sesuai dengan kenyataan. (Paramita, Wawancara 2020)

Penekanan realitas agar masyarakat memiliki persepsi dan pandangan terhadap peristiwa yang terjadi di pemerintahan digunakan Tempo dalam menggambarkan suatu peristiwa di dalam cover majalah.

"Bahwa ini pelemahan KPK gitu bukan penguatan justru pelemahan gituloh dan dari situ dapat disimpulkan bahwa ini yang terjadi sekarang tidak sesuai dengan yang beliau janjian pada saat kampanye dulu". (Paramita, Wawancara 2020)

Pada dasarnya majalah Tempo mengkonstruksi makna mengenai realitas dengan menciptakan suatu cover majalah Tempo yang dibangun atas suatu eksternalisasi, seperti pendapat wawancara di atas eksternalisasi disini dimana usaha dalam pencurahan ide dalam bentuk simbol baik gambar maupun tulisan merupakan hasil dari media dalam menangkap fenomena yang terjadi di masyarakat, terkait dengan penelitian ini majalah Tempo melihat bahwa peristiwa yang saat itu sedang ramai mengenai kisruh revisi UU KPK. yang dilihat berdasarkan fakta-fakta peristiwa yang terjadi mengenai janji penguatan KPK pada saat kampanye pemilihan Presiden, namun pada saat revisi UU KPK itu disetujui oleh Jokowi. Majalah Tempo melihat ini sebagai suatu sebagai pelemahan terhadap KPK dan tidak sesuai dengan janji yang diberikan pada saat kampanye.

Selanjutnya terdapat objektifitas yaitu dimana media memiliki analogi yang objektif mengenai suatu keadaan saat ini yaitu kisruh revisi UU KPK yang akan disahkan, terkait dengan gambar presiden Jokowi yang yang diidentikan sebagai kepala pemerintahan, yang seluruh kewenangan dan pusat keputusan ada pada kepala Negara.

"Kita sih gapernah berfikir sampe sejauh itu ya bahwa jadi setiap hal harus ada maknanya gitu, yang penting tujuan utama kita adalah menampilkan presiden sebagai simbol lalu ada bayangannya gitu dan itu saja sih fokusnya, mungkin ya kalau ada yang mau meneliti tentang maknanya sih sah-sah saja si bebas-bebas saja Cuma kalau saya pribadi sih aaaa saya maunya orang fokus di presiden dan bayangannya gitu". (Paramita, Wawancara 2020)

Majalah Tempo berusaha untuk menciptakan simbol yang relevan dengan peristiwa saat ini dengan membuat simbol Jokowi dan bayangannya dengan hidung panjang menyerupai Pinokio, analogi ini disesuaikan dengan kenyataan yang terjadi di Indonesia. Konstruksi pemahaman mengenai realitas dari analogi ini dipertegas berdasarkan hasil wawancara sebagai berikut

"Arahnya kesitu (Janji yang tidak dipenuhi, perkataan yang tidak sesuai dengan kenyataan) tapi masih membuka kemungkinan bahwa aa hmm jadi sampul ini tetap ada praduga tak bersalahnya ya bahwa ini bukan maunya Jokowi, itu ya tetap ada. Tapi indikasi dan faktafaktanya sejauh ini ya beliau menyetujui gitu kan, kampanye kan penguatan supaya terpilih... sebenernya bahwa ya Jokowi tidak menepati janji gitu. Sebenernya sih gol tujuan mulianya caelah tujuan mulianya adalah aaaa kita ingin apa ya kita mau masyarakat juga kritis gitu".(Paramita, Wawancara 2020)

Dalam hal ini realitas yang ingin dibangun oleh majalah Tempo adalah bahwa terjadi janji yang tidak ditepati, tidak sesuai perkataan pada saat kampanye oleh Jokowi.

Selanjutnya adalah eksternalisasi, dimana proses pengertian atau interpretasi dari peristiwa objektif, terkait dengan penelitian ini dengan penggunaan analogi presiden Jokowi, siluet hitam menyerupai Pinokio dan headline "Janji Tinggal Janji", simbol yang saling terkait ini dimaknai dengan realitas yang terjadi di Indonesia. Dari cover yang telah dirancang, majalah Tempo menciptakan pengetahuan di masyarakat. Majalah Tempo berusaha untuk membebaskan kepada masyarakat untuk memiliki pemahaman tentang cover majalahnya.

"Kalau interpretasinya diserahkan ke pembaca secara bebas gitu gapapa ga, iya maknanya secara sederhana sih aaa janji yang tidak ditepati sebenernya atau lebih sederhananya lagi perkataan yang tidak sesuai dengan kenyataan". (Paramita, Wawancara 2020)

"Gambaran ideal dari demokrasi dan itu 
udah jauh banget gitu dan dari apa yang selama ini kita dapatkan ini jauh lebih buruk gitu dan trennya kearah lebih buruk gitu kan nah dengan omnibus law dan segala macam gitu kan itu semuanya mengerikan gitu terus bagaimana keberpihakan kepada pengusaha, pengusaha tambang dan itukan tidak hanya bagi warga tapi juga kelestarian lingkungan itu juga parah kan dampaknya... Jadi masyarakat lebih kritis, melek politik, ga buta-buta amat minimal tau apa yang direncanakan oleh pemerintah dan legisatif". (Paramita, Wawancara 2020)

Realitas lain yang terdapat di dalam cover majalah Tempo merupakan gambaran demokrasi yang ada di Indonesia yang lebih buruk dengan omnibus law terlihat keberpihakan penguasa. Ini sesuatu yang perlu diperhatikan di Indonesia karena akan menciptakan suatu dampak bagi masyarakat. Disini majalah Tempo ingin mengajak masyarakat untuk kritis dan memiliki pengetahuan mengenai apa yang sedang terjadi di pemerintahan dan apa akan dirancanakan oleh pemerintah.

"Hmm ah iya, mengkhawatirkan ya. Jujur saya kecewa sih dengan kok bisa sampe ada sih revisi undang-undang terus kok mengkhawatirkan gitu kan, wah ini akan mengancam kebebasan pendapat dan agak aneh terjadi di jaman demokrasi dimana demokrasi sedang jaya-jayanya kok bisa terjadi sesuatu yang seperti ini”.

Cover majalah Tempo merupakan pandangan media akan suatu realitas, dalam cover ini majalah Tempo berusaha ingin menggambarkan kekecewaannya terhadap revisi UU KPK yang menghawatirkan dan dapat mengecam kebebasan berpendapat yang harusnya diterapkan dalam sistem pemerintahan yang demokrasi.

"Hmm kalau Cover Storynya itu kan keputusan Redaksi, jadi eem setiap pecan kita meluncurkan empat laporan panjang. Salah satunya jadi cover story. Nah itu redaksi melalui rapat opini, mereka yang memilih mana yang layak untuk dijadikan cover story. Nah kalo di edisi itu memang kemarin $\mathrm{hmm}$ situasinya pun juga $\mathrm{hmm}$ apa ya, situasinya kan sedang intens ya soal isu ruu itu kan, revisi undang-undang itu kan, jadi aa pada waktu itu, itu isu yang paling kuat sih. Jadi magnetnya paling besar, isunya kuat terus apatuh namanya, layak untuk dipublikasikan seperti itulah". (Paramita, 2020)

Pada dasarnya majalah Tempo membuat Cover Story dibuat atas keputusan Redaksi, di edisi ini redaksi menetapkan tema melalui rapat opini, mereka yang memilih mana yang layak untuk dijadikan cover story. Ide dalam pembuatan cover majalah dari situasi yang terjadi saat ini, dan yang sedang intens mengenai isu revisi UU KPK ini, karena pada saat itu menjadi isu yang paling kuat, yang menjadi magnetnya paling besar maka layak untuk digunakan. Dalam proses perancangan revisi UU KPK ini cukup jelas dan beliau mengirimkan utusan ke sidang revisi UU KPK, makanya disitulah menggunakan gambar presiden, karena presiden sebagai simbol kepala pemerintahan yang berkontribusi dalam revisi UU KPK.

\section{KESIMPULAN}

Kesimpulan dari temuan dan hasil analisis dari konstruksi realitas dalam cover majalah Tempo Edisi 19-22 September 2019 yakni dalam mengkonstruksi realitas majalah Tempo menggunakan tanda baik gambar ataupun tulisan, dengan menggunakan model teori triadic Charles Sander Pierce dalam menganalisis maka dengan menggunakan objek yaitu sebagai berikut:

1. Penggunaan gambar Jokowi dan bayangannya dengan hidung panjang ini merupakan usaha majalah Tempo dalam pencurahan ide membentuk simbol dalam menangkap fenomena yang terjadi di masyarakat. Konstruksi pemahaman yang dibangun Majalah Tempo melihat bahwa peristiwa kisruhnya revisi UU KPK, dilihat berdasarkan fakta-fakta peristiwa yang terjadi mengenai janji penguatan KPK pada saat kampanye pemilihan Presiden, namun pada saat revisi UU KPK itu disetujui oleh Jokowi. Majalah Tempo melihat ini sebagai suatu sebagai pelemahan terhadap KPK dan tidak sesuai dengan janji yang diberikan pada saat kampanye.

2. Gambar Jokowi dengan banyangannya yang menyerupai pinokio jika dikaitkan dengan headline "Janji Tinggal Janji", konstruksi pemahaman mengenai realitas yang ingin dibangun oleh majalah Tempo 
adalah bahwa terjadi janji yang tidak ditepati, tidak sesuai perkataan pada saat kampanye oleh Jokowi. Jokowi dianggap berbohong terkait dengan janjinya untuk mendukung KPK, namun kenyataannya revisi UU KPK tetap akan disahkan. Penggambaran yang terdapat di dalam cover majalah Tempo sebagai gambaran mengenai kritis Tempo terhadap kondisi yang terjadi saat ini.

3. Konstruksi realitas yang ingin dibangun dari cover yang telah dirancang, majalah Tempo menciptakan pengetahuan di masyarakat. gambaran demokrasi yang ada di Indonesia yang lebih buruk dengan omnibus law terlihat keberpihakan penguasa. majalah Tempo berusaha ingin menggambarkan kekecewaannya terhadap revisi UU KPK yang menghawatirkan dan dapat mengecam kebebasan berpendapat yang harusnya diterapkan dalam sistem pemerintahan yang demokrasi. Majalah Tempo juga mengajak masyarakat untuk kritis terhadap sesuatu yang terjadi di Indonesia.

Dalam penelitian ini fokus yang diteliti mengenai teks dengan pisau analisis analisis semiotika, maka diharapkan penelitian selanjutnya dapat dilakukan dengan subjek dan metode lain seperti metode reception analisis untuk melihat penerimaan dari khalayak mengenai gambar cover majalah, sehingga penelitian selanjutnya berbeda dengan dengan penelitian ini karena melihat dari perspektif khalayak. Pada sisi lain penelitian ini bisa jadi bahan refrensi sekaligus evaluasi bagi redaksi media dalam menggambarkan realitas yang terjadi di masyarakat sehingga tidak terjadi multi tafsir dan dugaan di masyarakat mengenai sebuah penggambaran berita.

\section{REFERENSI}

Ardianto, E. dan bambang Q.-A. (2011). filsafat ilmu komunikasi. Simbiosa Rekatama Media.

Budiman, K. (2011). Semiotika Visual: Konsep, Isu, dan Problem Ikonisitas. Jalasutra.

Bungin, B. (2007). Sosiologi Komunikasi, Teori, Paradigma, Dan Diskursus Teknologi Komunikasi Di Masyarakat. Kencana.

Danesi, M. (2010). Pengantar Memahami semiotika Media. Jalasutra.

Detikcom, T. (2019). Superkilat, Ini Kronologi 13 Hari DPR-Jokowi Revisi UU KPK. 17 September 2019. https://news.detik.com/berita/d4709596/superkilat-ini-kronologi-13-haridpr-jokowi-revisi-uu-kpk

Effendy, O. U. (2006). Ilmu Komunikasi; Teori dan Praktek. Remaja Rosda karya.

Eriyanto. (2013). Analisis Isi Pengantar Metodologi untuk Penelitian Ilmu Komunikasi dan Ilmu-ilmu Sosial Lainnya. Kencana Perdana Media Group.

Kovach, B., \& Rosentiel, T. (2006). Sembilan Elemen Jurnalisme. Yayasan Pantau.

Krisyantono, R. (2006). Teknik Praktis Riset Komunikasi,. Kencana.

Noviani, R. (2002). Jalan Tengah Memahami Iklan. Pustaka Pelajar.

Paramita, K. (2020). Transkrip Wawancara.

Riana, F. (2019). Penjelasan Majalah Tempo Soal Sampul Bergambar Jokowi Nasional Tempo.co. Tempo.Co. https://nasional.tempo.co/read/1248507/pe njelasan-majalah-tempo-soal-sampulbergambar-jokowi

Rolnicki, T. E. (2008). Pengantar Dasar Jurnalisme (Scholastic Journalism). Kencana.

Setiawan, N. (2020). PEMAKNAAN COVER MAJALAH TEMPO (Analisis Semiotika Cover Majalah Tempo Edisi 16 September-22 September 2019). SOURCE : Jurnal Ilmu Komunikasi, 6(1), 81-88.

http://jurnal.utu.ac.id/jsource/article/view/ 1744

Shimp, T. A. (2003). Periklanan Promosi \& Aspek Tambahan Komunikasi Pemasaran Terpadu (5 Jilid 1). Erlangga.

Sobur, A. (2009). Semiotika Komunikasi. Remaja Rosda karya.

Syam, N. (2005). Islam Pesisir. LKis Pelangi Aksara.

Vera, N. (2014). Semiotika dalam Riset Komunikasi. Penerbit Ghalia Indonesia.

Wibowo, I. S. W. (2013). EBOOK Semiotika Komunikasi Aplikasi Praktis Bagi Penelitian dan Skripsi Komunikasi Edisi 2. Mitra Wacana Media. https://salakanews.com/download/downlo ad-ebook-semiotika-komunikasi/ 


\section{Jurnal Ilmu Komunikasi, Vol.8 No.2 September 2021}

PROFIL PENULIS

Laurensia Retno Hariatiningsih, M.I.Kom, pendidikan informal S1 Broadcasting di Sekolah Tinggi Ilmu Komunikasi Profesi Indonesia (Stikom Prosia) Jakarta dan Pascasarjana Sahid Jakarta dengan konsentrasi Media Baru dan Jurnalistik. Saat ini status sebagai dosen tetap Universitas
Bina Sarana Informatika.

Irwanto, latar belakang S1 Jurnalistik Institut Ilmu Sosial dan Ilmu Politik (IISIP) Jakarta dan tamat pascasarjana dengan konsentrasi media politik Universitas Mercu Buana Jakarta. Saat ini sebagai dosen tetap Univeristas Bina Asarana Informatika. 